\title{
NEW DATA ON THE GENUS EA DISTANT, 1911 (HEMIPTERA: HETEROPTERA: ACANTHOSOMATIDAE), WITH DESCRIPTION OF A NEW SPECIES FROM CHILE
}

\author{
NUEVOS DATOS ACERCA DEL GÉNERO EA DISTANT, 1911 (HEMIPTERA: HETEROPTERA: \\ ACANTHOSOMATIDAE), CON DESCRIPCIÓN DE UNA NUEVA ESPECIE DE CHILE
}

\author{
Máriom A. Carvajal ${ }^{1,2}$, Eduardo I. Faúndez ${ }^{1,2} \&$ David A. Rider ${ }^{1}$
}

\begin{abstract}
New distributional data is provided for Ea australis Distant, 1911 in Chile and Argentina. The presence of this species in the Magallanes Region of southern Chile is confirmed. On the other hand the northernmost record for this species is provided, from Neuquén Province in Argentina. The first hostplant records (Nothofagus pumilio and Nothofagus sp., Nothofagaceae) for Ea australis are provided. Ea septentrionalis $\mathrm{n}$. sp. is described from the highlands in Bíobío and Araucanía regions in Chile; thus extending the northern distributional limit known for Ea.
\end{abstract}

Key words: Heteroptera, Acanthosomatidae, Ea, new records, new species, Chile, Argentina.

\section{RESUMEN}

Se entregan nuevos datos distribucionales para Ea australis Distant, 1911 en Chile y Argentina. Se confirma la presencia de esta especie en Magallanes y se añaden nuevas localidades y se entrega la localidad más septentrional para Argentina. Se provee el primer registro de planta hospedadora (Nothofagus pumilio y Nothofagus sp., Nothofagaceae) para Ea australis. Se describe Ea septentrionalis n. sp. proveniente de zonas de altitud de las regiones del Bíobío y la Araucanía en Chile; extendiendo el límite norte de la distribución Ea.

Palabras clave: Heteroptera: Acanthosomatidae, Ea, nuevos registros, nueva especie, Chile, Argentina.

1 Entomology Department, North Dakota State University, Dept. 7650, P.O. Box 6050; Fargo, ND. ed.faundez@gmail.com, mariom.carvajal@gmail.com.

2 Departamento de Zoología Médica, Centro de Estudios en Biodiversidad (CEBCh), Magallanes, 1979. 


\section{INTRODUCTION}

Acanthosomatidae is a family of Pentatomoids commonly named shield bugs. The last world revision of the group was undertaken by Kumar (1974) who recognized around 200 species in 47 genera. Currently after several taxonomic changes, the number of valid genera in this family is 57 with about 230 species (Faundez et al. 2014).

There are few species of Acanthosomatidae in Chile; however Chilean and Patagonian fauna is almost completely endemic, and of great importance for the understanding of the whole family phylogeny (Faúndez et al. 2014). Carvajal \& Faúndez (2013) wrote that the Chilean fauna of Acanthosomatidae is comprised of 13 species classified in 12 genera. Later, Faúndez (2014) revalidated Pseudosinopla canaliculus (Reed, 1898) and erected a new genus to host it. Faúndez et al. (2014) erected a new genus and described a new species from southern Chile. As result currently we have 15 species in 14 genera distributed in Chile.

Ea Distant, 1911 is a monospecific genus of Acanthosomatidae distinguished by its characteristic body ovate shaped, fleshy ostiolar peritreme, and short abdominal tubercle (Faúndez, 2014). Its only species, Ea australis was described for by Distant (1911) from Lago Blanco, Chubut, Argentina. Kumar (1974) provided a new record for Argentina of a female in Rio Negro and the first record of this species for Chile that correspond to 5 males in Coyhaique, Aysén Region. Finally, Faúndez (2007) reported this species for the first time in Magallanes Region with 5 males and 5 females from Sierra Baguales. There is no more information about this genus, biology and/or host plants are unknown. The purpose of this work is to provide new information on this genus and to describe a new species from Chile.

\section{MATERIALS AND METHODS}

For morphological descriptions we follow Kumar (1974), and for the efferent system Kment \& Vilimova (2010). Photos were taken and edited with Auto-Montage, Syncroscopy ${ }^{\circledR}$. The map was elaborated with Panmap, Pangaea® .

Material examined is deposited in the following collections:

USNM United States National Museum, Smithsonian Institution, Division of Natural History

DARC David A. Rider Personal Collection

EIFC Eduardo I. Faundez Personal

\section{Collection}

MACC Máriom A. Carvajal Personal

Collection

\section{RESULTS}

Ea septentrionalis n.sp.

(Figs. 2, 4, 6, 8, 9, 10, 11)

General body shape oval and elongated (Fig. 9). Dorsum light green, uniformly colored, with light brown punctation, ventral portion reddish and yellowish.

Head: green with light brown punctures; paraclypei not surpassing the anteclypeus, lateral margins elevated, apices narrowly rounded, dorsal surface transversally striated with fine punctures (Fig. 2). Anteclypeus rounded in the apex with a few light brown hairs; eyes prominent, reddish; ocelli bright red, located posterior to the eyes, and not contiguous with pronotum; antennae unicolor, yellowish, first antennal segment thick, surpassing the apex of the anteclypeus, second segment longer than the third, fourth and fifth segments subequal; rostrum reaching the midcoxae, first segment at level with bucculae.

Thorax: Pronotum trapezoid with denser punctuation in the middle than in the sides, humeral angles rounded, slightly projected (Fig.2), cicatrices immaculate; scutellum isosceles triangle shaped with uniform thick punctures; clavus with three lines of punctures parallel to the lateral margin of the scutellum; Hemelytra: Corium divided in two puncture design sections, the inner section with thicker punctures and the outer section weaker punctures; membrane slightly yellowish. Metapleuron: Ostiole elongated transversally, ostiolar peritreme fleshy making look the ostiole like a triangle, evaporatorium reddish, diagonally striated, 
metepimeral pseudosuture smooth, with red and yellow spots; Legs: uniformly yellow-greenish, femora thick, with basal and apical portions constricted, tibiae cylindrical (i.e. without a median sulcus), tarsi bisegmented.

Abdomen: Connexiva rounded, bicolored, each conexival segment reddish, with the anterior portion yellowish; base of the abdomen with a small tubercle, reaching but not surpassing metacoxae; ventral surface yellowish-green with a bright red zig-zag designed border around it that does not cover the spiracles; spiracles light brown colored; two pairs of Pendergrast's organs, located on $6^{\text {th }}$ and $7^{\text {th }}$ sternite on each side, not contiguous.

Male genitalia: Posterior margin of pygophore bilobed (Fig. 4), lateroposterior sides wide and proyected (Fig. 4), presence of a pack of light brown pilosity on its middle border. Parameres lanceolated (Fig. 6), sharpened, wide and pointed apically (Fig. 8) with a median process in the anterior surface; coloration reddish in the base and darkening brown to black in the apex.

Female genitalia (Fig. 10): $1^{\text {st }}$ gonocoxae mostly rectangular shaped, striated diagonally, yellowish in the middle and reddish on the sides. $2^{\text {nd }}$ gonocoxae very small, almost imperceptible, rounded in the apex. Paraterguites 8 rounded, reddish in the inner side and yellowish-green on the outer side with some long light brown hairs. Paraterguites 9 triangular shaped with red and yellow spots.

Measurements ( $\mathrm{mm}$; male followed by female in parentheses). Total length:11.21 (10.61); head length: 1.55 (1.52), head width: 2.52 (2.45); antennal segments: I - 0.85, II 1.55, III - 0.92, IV - 2.23, V: 3.47; rostral segments: I -1.02 , II -1.18 , III -1.55 , IV 0.61 ; pronotum length: 2.87 (2.78), pronotum width: 5.34 (5.49); scutellum length: 3.18 (3.33), scutellum width: 2.85 (2.96).

Etymology: from the latin septentrionalis which means northern. This name has been assigned to this species because of its distribution. The type species of the genus has been named australis, which means southern, and matches with its distribution in the Austral Chilean and
Argentinean Patagonia. This new species, however, is distributed in a more northern location in Chile.

Holotype: Chile: Nuble Province, ShangriLa, SW side of Volcan Chillan, 1600m.; 19-21I-1979; Leg. D \& M Davis \& B. Akerbergs $1{ }^{\Uparrow}$. USNM

Paratypes: CHILE: Bíobío Region: Ñuble Province, Shangri-La, SW side of Chillan Volcano, 1600m.; 19-21-I-1979; Leg. D \& M Davis \& B. Akerbergs; $10 ð \widehat{\jmath} 12$ [ [USNM (1 couple MACC)]. Shangri-La, Las Trancas, Cordillera de Ñuble, 1600m.; 19-22-I-1979; Leg. L.E. Peña; 2ภิ 1 ㅇ [USNM]. Nuble Province: Volcán Chillán, Las Cabras; 1480m.; 12-X-1954; Leg. L.E. Peña; 10 1 , [USNM]. Araucanía Region: Pino Hachado,

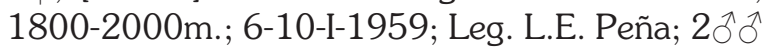
[DARC]. Termas de Tolhuaca; I-1959; Leg. L.E. Peña; 1 ㅇ [DARC].

Discussion: This species can be differentiated from Ea australis because of the shape of pronotum which is larger and wider; with sides more inclined in Ea septentrionalis (see figs. 1 and 2). The pygophore in ventral view is wider with lateroposterior edges convex in Ea septentrionalis (Fig. 4); whereas this structure is compact with lateroposterior edges nearly straight in Ea australis (Fig. 3). The same structure is wide in caudal view with parameres occupying a bigger relative area in $E a$ septentrionalis (Fig. 6); whereas the pygophore is more compact and truncate, with parameres occupying a less relative area in Ea australis (Fig. 5). The parameres are lanceolated with a wide apex and having a process in the apex that looks like a spine oriented backwards in $E a$ septentrionalis (Fig. 8); whereas the parameres are lanceolated, without a wide apex and without any process in Ea australis (Fig. 7).

Ea australis Distant, 1911

(Figs. 1, 3, 5, 7, 11)

Besides of the records for Ea australis from Rio Negro in Chubut in Argentina, Coyhaique in Aysén Region and Sierra Baguales 
in Magallanes Region in Chile, anything else is known for this species. Here we add new records for this species for Argentina and Chile. Additionally the first host records for this species are provided.

Material Examined: ARGENTINA: Neuquén province: Lago Hermoso, Parque Nacional Lanin; XI-1949; Leg. Schajovskoi; 19 [USNM]. Lago Hermoso, Parque Nacional Lanin; XI-1949; Leg. M. Barrera; 19 [USNM]. Chubut province:

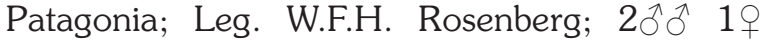
[USNM]. CHILE: Aysén Region, Coyhaique, Rio Simpson; 7-9-III-1961; Leg. L.Pena; $1 \hat{\jmath} 2$ 2우 [DARC]. Magallanes Region: Puerto Prat; 1-II1941; Leg. J. Herrera; $1 \widehat{\jmath}$ [USNM]. Magallanes Region, Ultima Esperanza, Cerro Castillo; X-2008; 19; ex Nothofagus pumilio [EIFC]. Magallanes Region, Última Esperanza, Cueva del Milodón; II-2004; Leg. T. Cekalovic; $1 \partial^{\lambda}$; on Nothofagus sp. [EIFC].
Key to the species of Ea Distant

1(2) Pronotum about 1.4 to 1.8 times longer than the head, sides well inclined and wide aspect, (Fig.2), lateroposterior margins of pygophore convex (Fig. 4). Ea septentrionalis n. sp.

2(1) Pronotum subequal (1.1 to 1.2 times longer) to the length of the head, sides less inclined and without wide aspect (Fig. 1), lateroposterior margins of pygophore nearly straight (Fig. 3)................... Ea australis Distant

\section{CONCLUSIONS}

$\mathrm{Ea}$ australis is associated with Nothofagus forests, just like several of the southern South America Acanthosomatids (Carvajal \& Faundez, 2013). One specimen was observed in Nothofagus pumilio (Poepp. et Endl.) Krasser, inside the bark of the tree; it probably indicate its use as a winter refuge. The new records extend the southern and northern distribution

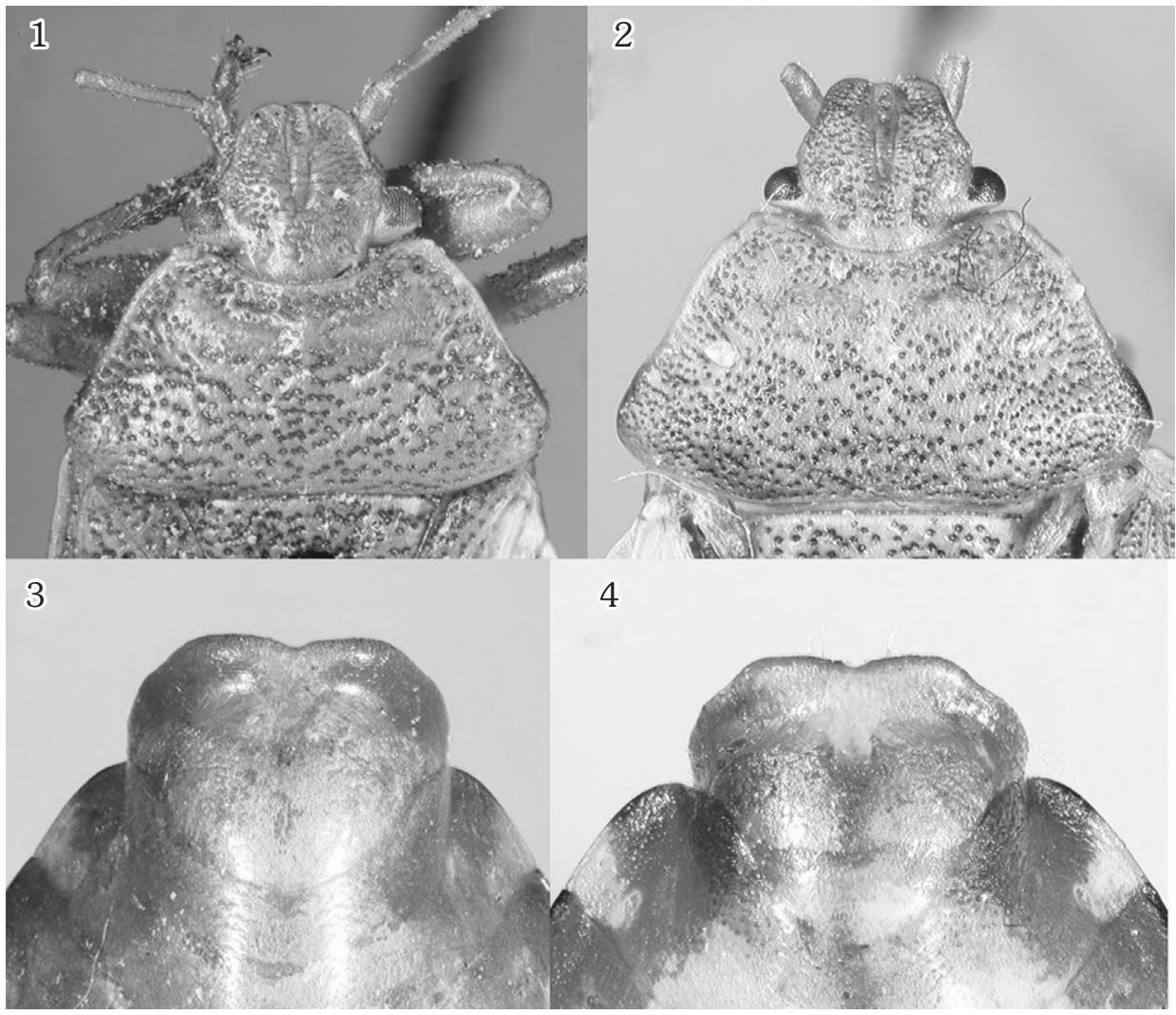

Fig. 1. Ea australis Distant, 1911, head and pronotum; Fig. 2. Ea septentrionalis n. sp., head and pronotum; Fig. 3. Ea australis, male pygophore, ventral view; Fig. 4. Ea septentrionalis, male pygophore, ventral view. 


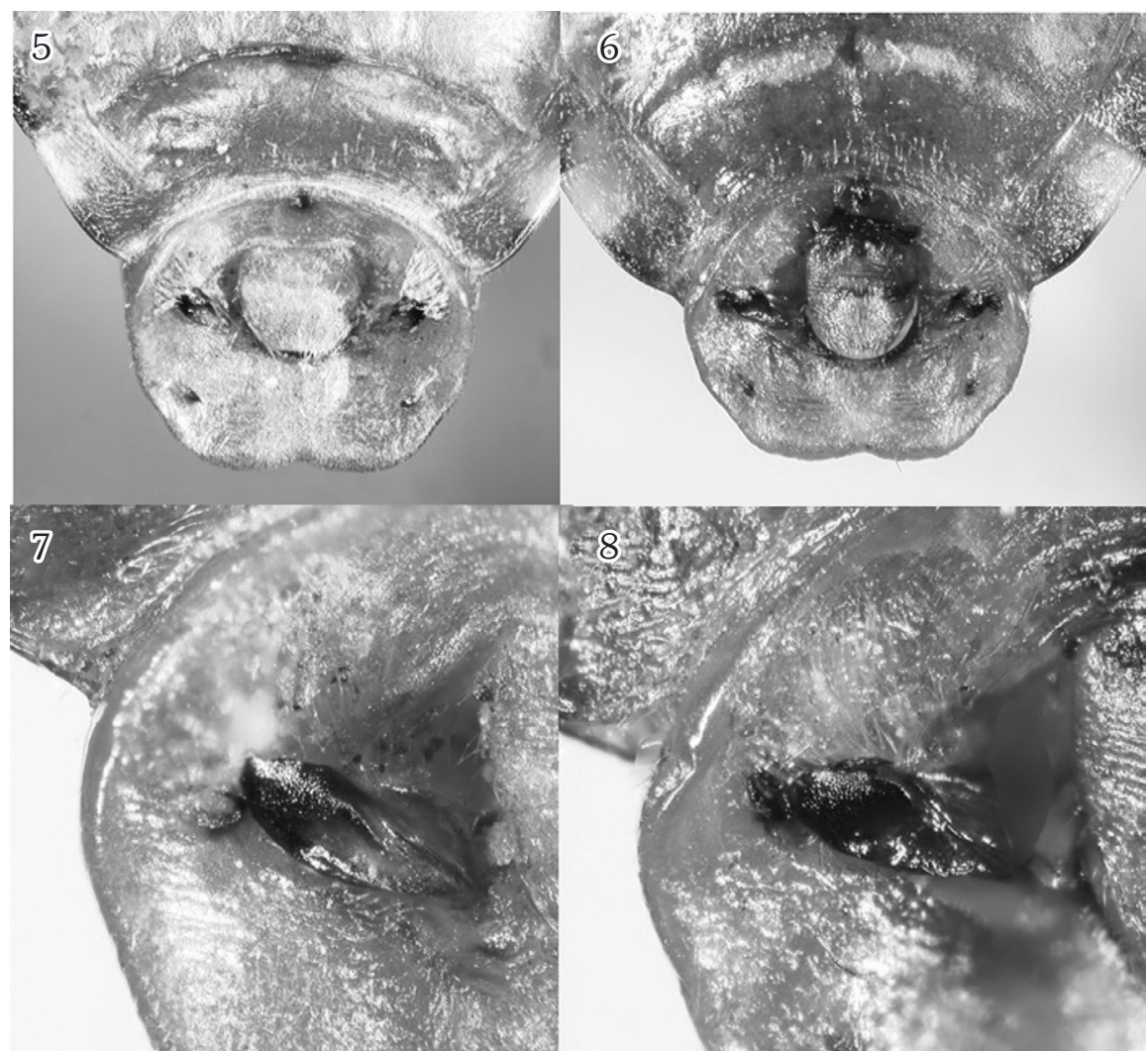

Fig. 5. Ea australis Distant, 1911, male pygophore, caudal view, parameres in natural position; Fig. 6. Ea septentrionalis n. sp. male pygophore, caudal view, parameres in natural position; Fig. 7. Ea australis, apex of paramere, detail; Fig. 8. Ea septentrionalis, apex of paramere, detail.

9

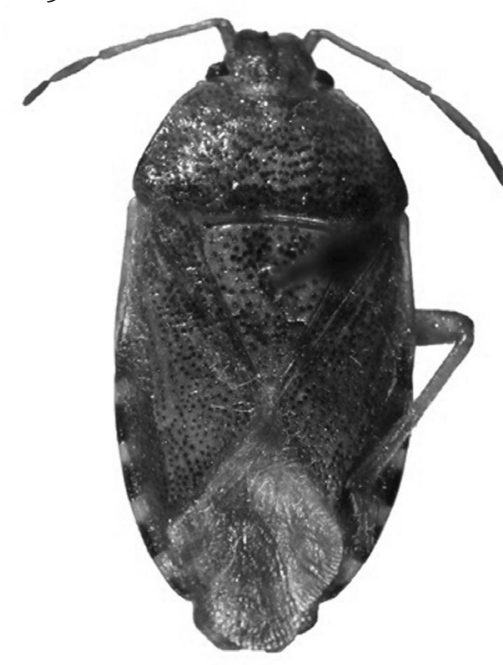

10

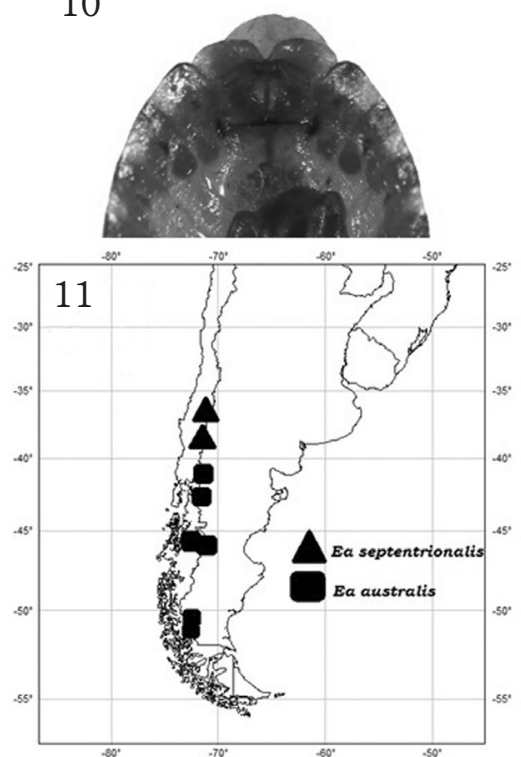

Fig. 9. Ea septentrionalis n.sp., habitus; Fig. 10. Ea septentrionalis, female terminalia; Fig. 11. Distribution of the species of Ea Distant, 1911. 
of this species (Fig. 11), and confirm its presence in the Magallanes Region. On the other hand Ea septentrionalis is distributed in the highlands $1600 \mathrm{~m}$ to $2200 \mathrm{~m})$ near volcanoes from Bíobío to Araucanía Regions in Chile (Fig. 11). We believe that this species is also associated with Nothofagus forests; however further research is needed in order to elucidate its biology.

\section{ACKNOWLEDGEMENTS}

We thank Thomas Henry (USNM) for providing us access to the specimens deposited in the USNM.

\section{LITERATURE CITED}

Carvajal, M. A. \& E. I. Faúndez (2013). Rediscovery of Sinopla humeralis Signoret, 1864 (Hemiptera: Heteroptera: Acanthosomatidae). Zootaxa, 367(2): 190-196.

Distant, W. L. (1911). Rhynchotal notes. - LIII. Neotropical Pentatomidæe. Annals and
Magazine of Natural History, (8)7:242258.

Faúndez, E. I. (2007). Lista de las especies de Acanthosomatidae (Insecta: Hemiptera) de la Región de Magallanes (Chile). Anales del Instituto de la Patagonia, 35(1): 75-78

Faúndez, E. I. (2014). A new genus for a Chilean species of Acanthosomatidae (Hemiptera: Heteroptera). Zootaxa, 3768(5): 596-600.

Faúndez, E. I., M. A. Carvajal, \& D. A. Rider (2014). Archaeoditomotarsus crassitylus, gen. and sp. nov. from Chile. Zootaxa, 3860(1):87-91.

Kumar, R. (1974). A revision of world Acanthosomatidae (Heteroptera: Pentatomoidea): Keys to and descriptions of subfamilies, tribes and genera, with designation of types. Australian Journal of Zoology, 34: 1-60.

Kment, P. \& J. Vilímová (2010). Thoracic scent efferent system of Pentatomoidea (Hemiptera: Heteroptera): a review of terminology. Zootaxa, 2706: 1-77. 